\title{
Aktualny stan wiedzy na temat patomorfologii cyfrowej
}

\section{Current state of knowledge about digital pathology}

\author{
Monika Prochorec-Sobieszek, Anna Szumera-Ciećkiewicz \\ Zakład Diagnostyki Hematologicznej, Instytut Hematologii i Transfuzjologii, Warszawa
}

\begin{abstract}
Streszczenie
W ostatnich latach widoczny jest dynamiczny postęp technologiczny obejmujacy wprowadzanie $w$ dziedzinie patomorfologii innowacyjnych rozwiazań opartych na obrazowaniu cyfrowym. Mikroskopia wirtualna polega na tworzeniu, przegladaniu, zarzadzaniu, dzieleniu sie, analizie i interpretacji obrazów cyfrowych catych preparatów mikroskopowych (WSI, whole slide imaging). Systemy WSI wraz z cyfrowymi platformami konsultacyjnymi maja zastosowanie $w$ edukacji, badaniach naukowych, telepatologii, telekonsultacjach i rutynowej diagnostyce. Systemy te zapewniaja przyjazne dla uzytkownika, szybkie $i$ interaktywne dzielenie sie obrazami cyfrowymi preparatów mikroskopowych. Niejednokrotnie rozbudowa systemu pozwala na integracje z pozostatymi medycznymi systemami informatycznymi. Aplikacje obejmujace analize obrazu i komputerowe wspomaganie diagnozy utatwiaja standaryzacje wyników badań naukowych i wspomagaja doktadność diagnostyczna. Mikroskopia wirtualna ma wiele zalet, jednak trzeba pamiętać o jej ograniczeniach, które obejmuja przede wszystkich duże inwestycje w sprzet i infrastrukturę, standaryzacje jakości uzyskiwanych obrazów cyfrowych i liczne obawy patomorfologów przed jej zastosowaniem w rutynowej diagnostyce.
\end{abstract}

Słowa kluczowe: patomorfologia cyfrowa, obrazy cyfrowe całych preparatów mikroskopowych, telepatologia, telekonsultacje, edukacja, badania naukowe, archiwizacja, diagnostyka cyfrowa, technologie IT

Hematologia 2017; 8, 1: 1-11

\begin{abstract}
In recent years, dynamic technological progress has been made, including the introduction of innovative solutions based on digital imaging in the field of pathomorphology. "Virtual microscopy" includes creating, viewing, managing, sharing, analyzing, and interpreting digital images of conventional microscope glass slides (WSI whole slide imaging). WSI systems, along with digital consulting platforms, are used in education, research, telepathology, teleconsultation, and routine diagnostics. Moreover, these systems provide user-friendly, fast and interactive sharing of digital images of microscopic specimens. Often, the development of the system allows integration with other medical IT systems. Applications that include image analysis and computer-assisted diagnosis facilitate the standardization of research results and support diagnostic accuracy. Virtual microscopy has many advantages, but it must be kept in mind that its limitations include high investment in equipment and infrastructure, the standardization of the quality of the digital images obtained, and the numerous concerns of pathomorphologists prior to its use in routine diagnostics.
\end{abstract}

Key words: digital pathomorphology, whole slide images, telepathology, teleconsultation, education, research, archiving, digital diagnostics, IT technologies

Hematologia 2017; 8, 1: 1-11

Adres do korespondencji: Monika Prochorec-Sobieszek, Zakład Diagnostyki Hematologicznej, Instytut Hematologii i Transfuzjologii, ul. Indiry Gandhi 14, 02-776 Warszawa, e-mail: monika.prochorec@interia.pl 


\section{Wprowadzenie}

Diagnostyka patomorfologiczna nowotworów $z$ równoczesnym określeniem czynników prognostycznych i predykcyjnych stanowi kluczowy etap we właściwym podjęciu procesu terapeutycznego. Dotychczasowe metody diagnostyki w patomorfologii uwzględniają, oprócz obrazu mikroskopowego, barwienia dodatkowe (histochemia, immunohistochemia) oraz wybrane techniki biologii molekularnej, w tym chromogenną i fluorescencyjną hybrydyzację in situ (FISH, fuorescence in situ hybridization). Gwałtowny postęp technologii informatycznych pozwolił na niemal całkowitą digitalizację między innymi w radiologii, której podstawą są obecnie wyłącznie obrazy cyfrowe. Są one również szeroko wykorzystywane w urologii i kardiologii. Wprowadzenie patomorfologii cyfrowej (digital pathology) wymaga przede wszystkim uzyskania wysokiej jakości cyfrowych obrazów całych preparatów mikroskopowych (WSI, whole slide imaging). W skład tego procesu wchodzą wytworzenie obrazów cyfrowych $z$ preparatów mikroskopowych przy użyciu skanera oraz interpretacja i analiza uzyskanych obrazów za pomocą specjalistycznego oprogramowania (dedykowanych przeglądarek) [1,2] (ryc. 1). Technika WSI polega na zastąpieniu konwencjonalnej mikroskopii świetlnej obrazem cyfrowym dostępnym na poziomie komputera lub urządzeń mobilnych. Patomorfologię cyfrową można zatem zdefiniować jako tworzenie, przeglądanie, zarządzanie, dzielenie się, analizę i interpretację obrazów cyfrowych uzyskanych $z$ preparatów mikroskopowych. Zastosowania patomorfologii cyfrowej obejmują diagnostykę oraz działalność naukową. Do celów diagnostycznych szczególnie przydatne wydaje się zastosowanie telepatologii i telekonsultacji, jak również możliwość archiwizacji badań w postaci cyfrowej. Udział WSI w badaniach naukowych i edukacji $z$ roku na rok istotnie zyskuje na znaczeniu. Postęp w rozwoju cyfrowej patomorfologii jest możliwy dzięki dynamicznej modernizacji urządzeń skanujących, stałemu zwiększaniu mocy obliczeniowych komputerów i prędkości transmisji danych, wprowadzaniu nowych rozwiązań w oprogramowaniach oraz technologii gromadzenia dużych ilości informacji. Możliwość ścisłej integracji procesu rozpoznawania i leczenia nowotworów dzięki ułatwieniu współpracy z zespołami lekarzy innych specjalności zajmującymi się diagnostyką i leczeniem tych chorób stanowi jedną $z$ ważnych zalet cyfryzacji w patomorfologii [1-11].

W klasycznej patomorfologii opartej na mikroskopii świetlnej interpretacja obrazów komórek i tkanek odbywa się w rozdzielczości wyższej od rozdzielczości ludzkiego oka. Od XVII wieku i udoskonalenia przez Antoniego van Leeuwenhoeka mikroskopu świetlnego stanowił on podstawowe narzędzie patomorfologa. Wraz $z$ wprowadzaniem coraz lepszej optyki urządzeń i zwiększeniem rozdzielczości obrazów mikroskopowych poprawiały się warunki oceny preparatów mikroskopowych [12]. W rutynowej diagnostyce patomorfologicznej obowiązującym standardem nadal jest ocena preparatów w mikroskopie świetlnym. W ostatnich 25 latach techniki optyczne w patomorfologii wzbogacono o możliwość instalacji w mikroskopach świetlnych aparatów cyfrowych do zdjęć statycznych i kamer wideo umożliwiających ocenę preparatów mikroskopowych w czasie rzeczywistym. Technika ta pozwoliła na wprowadzenie pierwszych telekonsultacji obrazów mikroskopowych poprzez sieć komputerową między patomorfologami znajdującymi się w odległych lokalizacjach oraz na zdalne wykonywanie badań śródoperacyjnych. Tym niemniej, ze względu niewystarczającą rozdzielczość, jakość obrazów była stosunkowo niska [13-16]. W ostatnim dziesięcioleciu intensyfikacja postępu technicznego umożliwiła wprowadzenie skanerów preparatów mikroskopowych. Dzięki nim można wykonywać cyfrowe zdjęcia całych preparatów mikroskopowych. Skanery mają zalety zarówno obrazów $z$ kamer pracujących $\mathrm{w}$ czasie rzeczywistym (dostępność całych preparatów), jak i aparatów cyfrowych (wysoka rozdzielczość) $[12,16]$.

Mimo niekwestionowanych atutów mikroskopii wirtualnej trzeba pamiętać o jej ograniczeniach. Ma to szczególne znaczenie przy wdrażaniu cyfryzacji do rutynowej diagnostyki patomorfologicznej. W niniejszym artykule autorki uwzględniły zalety i wady patomorfologii cyfrowej oraz omówiły jej zastosowanie $\mathrm{w}$ praktyce klinicznej i działalności naukowej.

\section{Wymagania infrastruktury w patomorfologii cyfrowej}

Podstawą infrastruktury w patomorfologii cyfrowej są systemy WSI obejmujące skanery preparatów mikroskopowych i urządzenia wchodzące w skład technologii informacyjnych (IT, information technology). Skaner składa się z mikroskopu optycznego wyposażonego w jeden lub kilka aparatów cyfrowych do robienia zdjęć, tradycyjnych i fluoroscencyjnych źródeł światła, automatycznego lub ręcznego podajnika preparatów mikroskopowych, stacji roboczej oraz oprogramowania umożliwiają- 


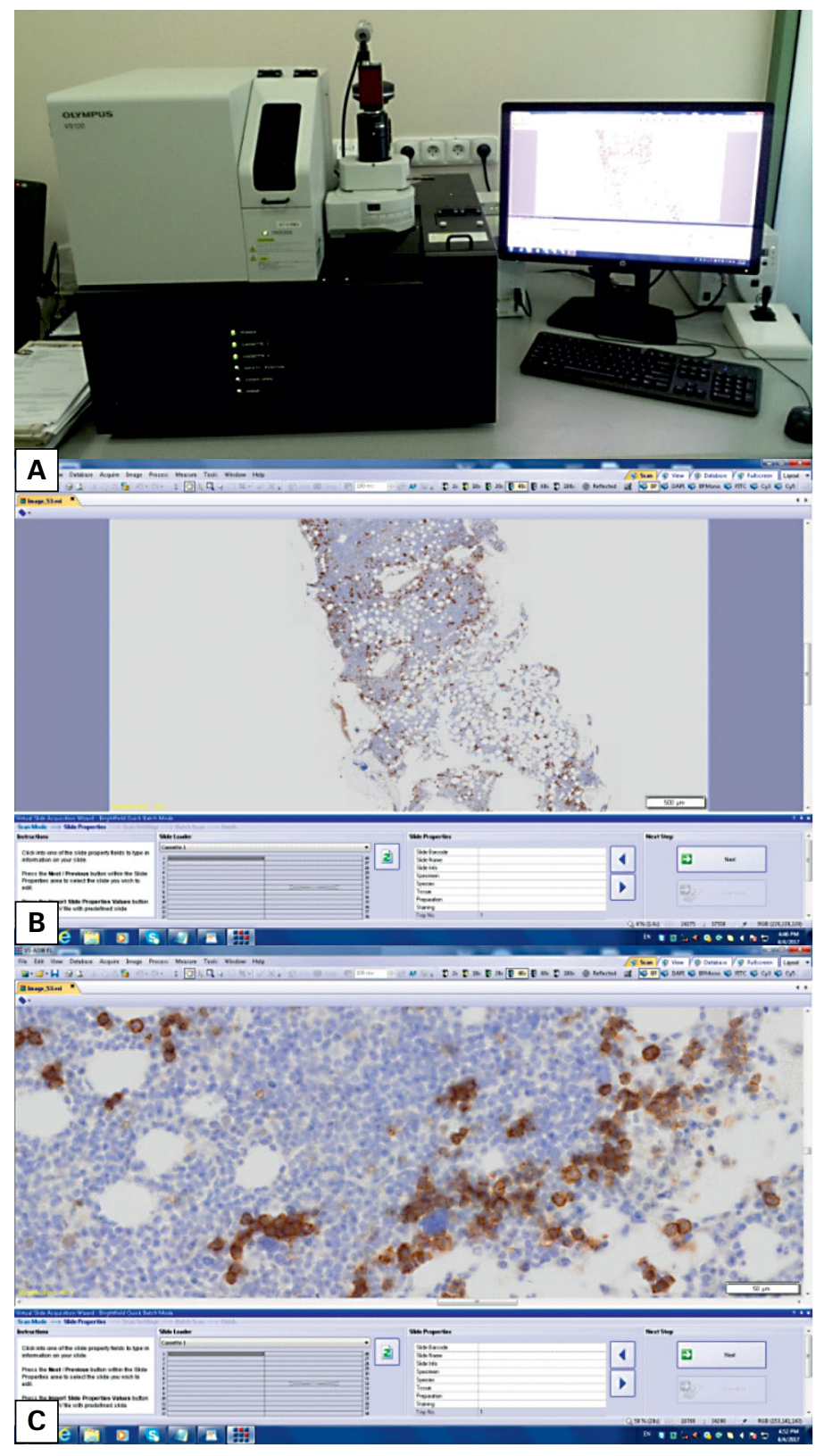

Rycina 1. Mikroskopia wirtualna polega na tworzeniu, przeglądaniu, zarządzaniu, dzieleniu się, analizie i interpretacji obrazów cyfrowych całych preparatów mikroskopowych (WSI, whole slide imaging): A. Skaner preparatów mikroskopowych; B. Widok na ekranie monitora zeskanowanego preparatu pochodzącego z trepanobiopsji; C. Oprogramowanie zapewniające możliwość analizy obrazu cyfrowego w wybranym polu widzenia i powiększeniu (zazwyczaj obiektywy z maksymalnym powiększeniem 40 ×), a także między innymi nanoszenia notatek czy zaznaczania wybranego obszaru (na zdjęciach przedstawiono część wyposażenia Pracowni Patomorfologii Cyfrowej Instytutu Hematologii i Transfuzjologii, którego zakup zrealizowano z dofinansowania projektu nr POIG.02.03.00-14-111/13 sfinansowanego z Programu Operacyjnego Innowacyjna Gospodarka 2007-2013, „Priorytet II. Infrastruktura strefy B+R, Działanie 2.3. Inwestycje związane z rozwojem infrastruktury informatycznej nauki")

Figure 1. Virtual microscopy is based on the creation, viewing, management, sharing, analysis and interpretation of whole slide imaging (WSI); A. Scanner of microscope preparation; B. Screen view of the scanned preparation derived from trepanobiopsy; C. Software provides the ability to analyze digital images in the selected field of view and magnification (usually lenses with a maximum magnification of $40 \times$ ) are used. Apply notes or mark the selected area is also possible (the pictures show part of Digital Pathology Laboratory infrastructure, Institute of Hematology and Transfusion, Warsaw, Poland. It was realized from the Project POIG.02.03.00-14-111/13 funded by Operational Programme Innovative Economy 2007-2013, “Priority II. R\&D Infrastructure, Measure 2.3. Investments connected with development of IT infrastructure of Science") 
cego przeglądanie zdjęć $z$ możliwością dowolnego pozycjonowania i powiększenia analogicznie do konwencjonalnej mikroskopii świetlej. Infrastruktura IT obejmuje natomiast komputer $z$ oprogramowaniem do pozyskiwania i obróbki obrazów cyfrowych oraz do zarządzania plikami obrazów, serwery wraz z pamięcią zewnętrzną do przechowywania obrazów cyfrowych, a także bezpieczną i stabilną wysokoprzepustową sieć komputerową zapewniającą łączność między stacjami roboczymi, serwerami i pamięciami zewnętrznymi przechowującymi zeskanowane obrazy [4].

\section{Skanery preparatów mikroskopowych}

Obecnie są dostępne skanery preparatów mikroskopowych różnych producentów, które różnią się określonymi parametrami technicznymi. Najczęstsze różnice dotyczą pojemności określanej mianem liczby jednocześnie załadowanych szkiełek mikroskopowych oraz typu podajnika preparatów mikroskopowych (ręczny $v$. automatyczny). W tych urządzeniach wykorzystuje się także odmienne techniki tworzenia obrazów. Dwie podstawowe metody obejmują skanowanie liniowe, które polega na precyzyjnym liniowym przesuwie statywu $z$ kamerą nad preparatem i skanowanie linia po linii oraz skanowanie $z$ użyciem kamery CCD (charge coupled device), która wykonuje cyfrowe zdjęcia kolejnych drobnych kwadratowych pól obszaru preparatu. Proces uzyskiwania ostatecznego cyfrowego obrazu preparatu kończy się w momencie scalenia powstałych linii lub kwadratowych pól [12]. Skanery charakteryzują obiektywy o różnych powiększeniach i numerycznych aperturach; najczęściej o 20- i 40-krotnym powiększeniu. Część $z$ nich może wykonywać tak zwane skanowanie wielowarstwowe w technologii $z$-stacking. Choć obraz trójwymiarowy (3D, 3-dimensional) ma znacznie większy rozmiar (do kilkunastu GB [gigabyte]) i czas skanowania jest istotnie wydłużony, to jego zaletą jest możliwość zastosowania do oceny rozmazów cytologicznych, skrawków mrożonych oraz innych grubych preparatów, w przypadku których konieczna jest ewaluacja na różnych poziomach. Ocena indeksu proliferacyjnego i liczenie mitoz także są prostsze, gdy istnieje możliwość oglądania preparatów w wielu płaszczyznach. Skanery są często wyposażane we fluoroscencyjne źródło światła i specyficzne czujniki poprawiające jakość skanowanego obrazu. Ten typ urządzeń zapewnia wykonywanie skanów komórek i tkanek, których poszczególne struktury są znakowane barwnikami fluoroscencyjnymi, a następnie ich konwersję do kolorowych obrazów o wysokiej rozdzielczości. Skanery różnią się też formatami plików, w których są zapisywane zeskanowane obrazy. Najczęściej są to formaty zamknięte - często przypisane wyłącznie do jednego producenta, rzadziej formaty otwarte, zwykle zapisywane jako pliki standard jpeg 2000 albo standard DICOM (digital imaging and communications in medicine) $\mathrm{z}$ kompresją do jpeg (2000) [17].

Zachowanie wysokiej rozdzielczości i precyzji w odwzorowaniu szczegółów preparatów mikroskopowych cyfrowych obrazów WSI wpływa na rozmiar powstającego pliku. Zakres rozmiarów plików sięga od kilkunastu MB (megabyte) do kilkudziesięciu GB. Wielkość plików zależy również od pola powierzchni skanowanego preparatu mikroskopowego. Przykładowy obraz cyfrowy uzyskany w rozdzielczości 1600 megapikseli ma rozmiar około 4,6 GB [10]. Należy podkreślić, że obrazy WSI są znamiennie większe od plików cyfrowych uzyskiwanych w radiologii [18]. W celu minimalizacji rozmiarów plików można wykorzystywać między innymi algorytmy ograniczające obszar skanowania wyłącznie do pól zawierających tkankę oraz techniki kompresji obrazu [4]. Czas skanowania preparatów mikroskopowych zależy przede wszystkim od pola powierzchni, którą zajmuje skanowany materiał. Ponadto wpływają na niego poszczególne etapy pracy skanera, które obejmują obsługę szkiełek $z$ preparatami, proces skanowania i zadania końcowe scalające obraz cyfrowy. Uzyskanie jednowarstwowych skanów preparatów o wymiarach $15 \times 15 \mathrm{~mm}$ przy 40 -krotnym powiększeniu zajmuje od kilku do kilkudziesięciu minut w zależności od typu skanera [19].

O jakości obrazów cyfrowych decyduje wiele różnych czynników [20]. Znaczenie ma już sama jakość preparatów mikroskopowych, która zależy od prawidłowego utrwalenia i przeprowadzenia materiału tkankowego oraz pozbawionego wad technicznych procesu skrojenia, zabarwienia i zaklejenia preparatu, a następnie jakość technicznego wykonania obrazów cyfrowych w skanerach, która jest bezpośrednio powiązana $z$ charakterystyką skanera, w tym optyką urządzenia, metodami ogniskowania, zarządzania kolorami, balansem bieli i kontrastem. Istotnym czynnikiem jest także dokładność scalania składowych obrazów, stopień kompresji i kompletność uzyskanego końcowego obrazu cyfrowego, który powinien zawierać wszystkie fragmenty tkanki znajdujące się $\mathrm{w}$ preparacie mikroskopowym. Na korzystanie $z$ obrazu cyfrowego i jego przetwarzanie wpływa jakość wyświetlacza komputera albo projektora 
użytego do prezentacji tego obrazu. Czynniki $z$ tym związane to między innymi rozdzielczość ekranu, dokładność odwzorowania kolorów, jasność i kontrast. Wybór przeglądarki, a co za tym idzie płynność przewijania, możliwość użycia zmiennego ogniskowania oraz stan pozostałej infrastruktury IT przyczyniają się do zapewnienia wysokiej jakości w obsłudze, przetwarzaniu i prezentacji obrazów cyfrowych [20].

\section{Infrastruktura IT}

Zeskanowanie preparaty mikroskopowe są następnie udostępniane użytkownikom i mogą zostać zintegrowane $z$ laboratoryjnym systemem informatycznym (LIS, laboratory information system). Płynność w prowadzonej identyfikacji i archiwizacji skanów oraz połączenie LIS jest możliwe dzięki zastosowaniu do oznaczeń kodów kreskowych. Do przechowywania plików obrazów WSI niezbędna jest pamięć masowa o wystarczającej pojemności. Wielkość pamięci należy dostosować do szacowanej docelowej liczby obrazów cyfrowych. Przechowywanie sprecyzowanej liczby wybranych preparatów do celów konsultacyjnych, naukowych czy edukacyjnych nie wymaga zapewnienia zbyt dużej ilości pamięci. Rutynowe skanowanie wszystkich przypadków w średniej wielkości pracowni patomorfologii wymaga udostępnienia środowiska $z$ ogromną przestrzenią pamięci zewnętrznych sięgających $50 \mathrm{~TB}$ (terabyte) na rok oraz dodatkowego zabezpieczenia pamięci na kopie zapasowe, tak zwany backup [19]. Kontrolery i połączenia światlowodowe stosuje się zależnie od liczby skanerów oraz liczby użytkowników. Konieczność zapewnienia szybkiego dostępu do danych można rozwiązać, wykorzystując dyski w technologii SSD (solid-state drive). Jeśli nie wszystkie obrazy cyfrowe muszą być dostępne jednocześnie, to starsze obrazy mogą być archiwizowane na wolniejszych, ale tańszych taśmach magnetycznych. Wpływ na obróbkę cyfrowych obrazów ma jakość użytych wyświetlaczy, w tym ich rozdzielczość, która jest najważniejszym parametrem determinującym jakość obrazu i wielkość przedstawianego pola. Monitory o rozdzielczości $1600 \times 1200$ pikseli są w stanie wyświetlić zaledwie około $20 \%$ całości obrazu uzyskiwanego $\mathrm{w}$ konwencjonalnym mikroskopie świetlnym [21]. Na jakość obrazów cyfrowych wpływają również kalibracja kolorów, kontrast i jasność. O płynności w przekazywaniu obrazów decyduje przepustowość sieci, która powinna być odpowiednio wysoka, aby zapewnić szybkie przesyłanie dużych plików zawierających obrazy cyfrowe. Najczęściej przepu- stowość sieci $100 \mathrm{Mbs}$ (megabits per second) jest wystarczająca. W większości dostępnych na rynku przeglądarek internetowych są stosowane wydajne mechanizmy w celu zapewnienia właściwej szybkości przeglądania obrazów. Proces pobierania całych plików obrazowych przebiega etapowo i w czasie rzeczywistym $z$ pamięci dyskowych są udostępniane jedynie fragmenty analizowanej części całego obrazu. W celu szybszego dostępu do informacji przy kolejnych, późniejszych odwołaniach dane są składowane w pamięci podręcznej. Wiele przeglądarek umożliwia wyświetlenie obrazu w mniejszej rozdzielczości, zanim docelowo zostaną udostępnione wszystkie szczegóły w prezentacji obrazu o wysokiej rozdzielczości. Zastosowanie skonfigurowanych serwerów realizujących mechanizmy udostępniania obrazów $z$ pamięci podręcznej są stosowane w przypadku potrzeby udostępniania obrazów wielu użytkowników jednocześnie (np. w przypadku przeprowadzenia cyfrowych sesji konsultacyjnych lub kursów). Obecnie większość producentów zapisuje skanowane obrazy w plikach $z$ użyciem własnych formatów. Niestandardowe zamknięte formaty plików stanowią istotne utrudnienie dla użytkowników końcowych, ponieważ wymagają instalacji z góry określonych przeglądarek. Zastosowanie ujednoliconego formatu jpeg 2000 częściowo pozwala ominąć tę niedogodność [22].

\section{Zastosowanie obrazów cyfrowych w patomorfologii}

Wysoka rozdzielczość obrazów cyfrowych, większa szybkość skanowania, prostota w obsłudze przeglądarek i możliwość przesyłania obrazów na odległość (telepatologia) powodują, że wzrasta znaczenie wykorzystania systemów WSI w patomorfologii [4]. Mimo wielu niekwestionowanych zalet tej technologii obrazy cyfrowe są aktualnie wykorzystywane głównie do działań niezwiązanych bezpośrednio $z$ diagnostyką, między innymi do edukacji, archiwizacji obrazów materiału biologicznego, w trakcie spotkań multidyscyplinarnych oraz w prowadzeniu badań naukowych. Mimo braku regulacji prawnych $\mathrm{w}$ diagnostyce dopuszcza się implementację patomorfologii cyfrowej w formie telekonsultacji czy oceny wycinków tkankowych wbadaniach śródoperacyjnych.Zakres wykorzystania patomorfologii cyfrowej do rutynowej diagnostyki mikroskopowej jest bardzo ograniczony i nie może obecnie zastąpić patomorfologii konwencjonalnej — między innymi ze względu na brak stosownej infrastruktury sprzętowej oraz walidacji stosowanych metod [23]. 


\section{Diagnostyka cyfrowa}

Obecny stan techniki umożliwia wprowadzenie rutynowej diagnostyki cyfrowej, nadal jednak pozostaje wiele barier niepozwalających na kompletne ucyfrowionie zakładów patomorfologii. Oprócz zasadniczej bariery ekonomicznej widocznych jest kilka zasadniczych zagadnień wpływających na spowolnienie wprowadzania patomorfologii cyfrowej. Jeden $z$ istotnych powodów to fakt, $\dot{z}$ e obsługa laboratoryjnej linii technologicznej zakończonej wytworzeniem WSI zajmuje więcej czasu niż tradycyjna organizacja pracy; oprócz konieczności wytworzenia klasycznego preparatu mikroskopowego niezbędna jest realizacja dodatkowej procedury, tj. wykonania obrazu cyfrowego. Mimo wielu zalet diagnostyki cyfrowej większość patomorfologów jest przywiązanych do diagnostyki przy użyciu mikroskopów świetlnych, szczególnie jeśli ich edukacja przebiegała kilkanaście lat temu [23]. Diagnostyka przy użyciu mikroskopów świetlnych jest szybsza i łatwiejsza niż przy użyciu komputerów. W przeprowadzonych badaniach udowodniono, że rutynowa diagnostyka wykonywana przez patomorfologa za pomocą narzędzi cyfrowych jest średnio o $60 \%$ wolniejsza niż diagnostyka mikroskopowa [24]. Wprowadzenie rutynowej diagnostyki cyfrowej wiąże się $z$ ogromnymi nakładami inwestycyjnymi w strukturę IT szpitali i zakładów patomorfologii, obejmującymi sprzęt i oprogramowanie oraz konieczne dodatkowe szkolenie personelu [19]. Mimo gigantycznego postępu $\mathrm{w}$ technice skanowania metoda ta nie pozwala na zagwarantowanie w pełni wszystkich funkcjonalności nowoczesnych mikroskopów optycznych [23]. W zakładach patomorfologii stosujących w rutynowej diagnostyce obrazy cyfrowe wykazano niewielki odsetek błędu stanowiący 1-5\% [24-32]. Rozbieżności między oceną obrazów cyfrowych i konwencjonalnych wynikały przede wszystkim z niższej jakości obrazu i braku doświadczenia patomorfologa. Zakłady, których personel ma duże doświadczenie w patologii cyfrowej, osiągają rezultaty zbliżone do $82 \%$ zgodności rozpoznań w obu technikach obejmujących biopsję chirurgiczną [33]. W wielu opracowaniach dyskutuje się kwestię czasu skanowania i czasu potrzebnego do oceny obrazów cyfrowych. Im mniejszy jest wycinek, tym mniejsze pole powierzchni na szkiełku, a co za tym idzie krótszy czas skanowania i oglądania. Digitalizacja większych materiałów tkankowych zajmuje więcej czasu, a ponadto fragmenty wykraczające poza szkiełko nakrywkowe są skanowane w niższej jakości, zazwyczaj ze zmniejszona ostrością.
Choć większość badań wskazuje, że systemy WSI można efektywnie stosować również przy biopsjach gruboigłowych, preparaty słabo wybarwione pochodzące ze skąpego materiału mogą pozostać niezauważone dla systemów skanujących [34]. Systemy WSI można efektywnie wykorzystywać do archiwizacji rozmazów cytologicznych, głównie w celach edukacyjnych. Ograniczenia dla tego typu materiału wynikają $z$ konieczności uwzględnienia wielu płaszczyzn [35]. Skanowanie w technice $z$-stacking pozwala na uzyskanie odpowiednich jakościowo obrazów cyfrowych, lecz jest to technika czasochłonna [36].

Patologia cyfrowa umożliwia zastosowanie cyfrowej analizy obrazu. Oprogramowania do obliczeń ilościowych odczynów immunohistochemiczych ekspresji białek służą poprawie zwiększenia obiektywizacji oceny immunoreaktywności [37]. Jednym $z$ lepiej poznanych zastosowań analizy obrazu są aplikacje wspomagające ocenę barwień immunohistochemicznych dla receptorów estrogenowych, progesteronowych, białka HER2/ /Neu (human epidermal growth factor receptor 2) $\mathrm{i}$ indeksu proliferacyjnego Ki67 w raku piersi [38]. W badaniach porównawczych osiągnięto wyższy wskaźnik zgodności oceny ekspresji HER2/Neu z wynikami amplifikacji genu metodą FISH dla analizy opartej na obrazach WSI niż w ocenianych konwencjonalnie w mikroskopie świetlnym [39]. Mimo zachęcających rezultatów istnieją również ograniczenia analizy cyfrowej; między innymi przy ocenie liczby figur podziału $z$ zastosowaniem najbardziej zaawansowanego oprogramowania do analizy obrazu osiągnięto 80-85-procentową zgodność w porównaniu $z$ tradycyjną mikroskopią [40]. Analiza cyfrowa wydaje się przydatnym narzędziem informatycznym wspomagającym diagnostykę jednakże ocena ilościowa immunohistochemii stanowi wyłącznie niewielki procent całej diagnostycznej pracy lekarza patomorfologa.

Na podstawie systemów WSI zaczynają także powstawać aplikacje informatyczne komputerowego wspomagania diagnozy (CAD, computer-aided diagnosis) [41-43]. Aplikacje te korzystają zarówno z WSI, jak i narzędzi do automatycznej analizy obrazu. Zastosowanie CAD może obejmować między innymi stopniowanie histologiczne nowotworów (grading) i kwalifikację chorych do terapii [44]. Ponadto pozwala ono na automatyczne wybieranie obszarów do analizy w celu oceny tak zwanych hot spotów, czyli obszarów nowotworów o najwyższej aktywności proliferacyjnej [45]. Wspomaganie diagnostyki dotyczyło również badań nad systemami wyszukiwania i porównywania obrazów 
$z$ baz cyfrowych, jednakże aktualnie nie mają one zastosowania w rutynowej diagnostyce [46].

Telepatologia, czyli przesyłanie obrazów cyfrowych na odległość, obejmuje przede wszystkim konsultacje diagnostycznie trudnych przypadków (w celu uzyskania tzw. second opinion) oraz zdalne (na odległość) wykonywanie badań śródoperacyjnych. Cyfrowa diagnostyka śródoperacyjna materiałów mrożonych może stanowić jedyne wsparcie dla szpitali, w których nie ma możliwości wykonywania takich badań na miejscu między innymi $z$ powodu braku szpitalnego zakładu patomorfologii oraz lekarza patomorfologa. Telekonsultacje pozwalają na skrócenie czasu oczekiwania na wynik badania i mogą być one przeprowadzone w ciągu kilku godzin. Tradycyjna konsultacja wymaga przesyłania preparatów pocztą i zazwyczaj zajmuje kilka dni. Prowadzenie telekonsultacji wymaga zastosowania specjalistycznych oprogramowani, tak zwanych platform cyfrowych, na które lekarz patomorfolog przez Internet może przesłać preparaty w formie obrazu cyfrowego do innego konsultującego patomorfologa. W trakcie takiej konsultacji jest możliwe omówienie przypadku w czasie rzeczywistym (on-line). Jedna ze stron konsultujących przesuwa dowolnie obraz oraz zmienia powiększenia, podczas gdy pozostali uczestnicy telekonsultacji oglądają obrazy na ekranach swoich komputerów, tabletów i smartfonów. Analogicznie można przeprowadzać spotkania ekspertów $z$ różnych stron świata w określonych specjalistycznych obszarach patomorfologii w celu omówienia trudnych bądź ciekawych przypadków. Niewątpliwym atutem systemów WSI jest możliwość pracy zdalnej, na przykład $z$ domu lub $z$ dowolnego miejsca na świecie $[47,48]$.

W ośrodkach onkologicznych regularnie odbywają się spotkania zespołów multidyscyplinarnych, które również można prowadzić $z$ wykorzystaniem systemów WSI. Patomorfolodzy, omawiając szczegóły dotyczące chorych $z$ zespołem lekarzy (zazwyczaj złożonym $z$ onkologa, chirurga i radiologa), mogą prezentować w dowolnym miejscu na ekranach komputerów obrazy cyfrowe preparatów mikroskopowych [3].

Archiwizacja w patomorfologii polega na przechowywaniu szkiełek mikroskopowych i bloczków parafinowych oraz podlega ustawodawstwu dotyczącemu przechowywania dokumentacji medycznej. Preparaty i bloczki powinny być przechowywane minimum 25 lat, a ze względu na występowanie zmian rzadkich i unikatowych nie powinny ulegać utylizacji. Niestety, wiąże się $z$ tym wiele niedogodności, między innymi: konieczność dysponowania wentylowanymi pomieszczeniami magazynowymi o dużej powierzchni ze wzmocnionymi podłogami, możliwość uszkodzenia kruchych szkiełek mikroskopowych, blaknięcie barwień $z$ upływem czasu, złożona organizacja wypożyczeń i zwrotów preparatów. Tworzenie cyfrowych archiwów preparatów oparte na obrazach WSI zapewnia przechowywane ich bez utraty jakości (szczególnie preparatów immunofluorescencyjnych) oraz łatwość pobierania $z$ archiwum obrazów WSI do rekonsultacji, w celach edukacyjnych, do badań naukowych, organizacji spotkań kliniczno-patomorfologicznych i do zewnętrznych kontroli jakości. Jako obraz WSI do każdego przypadku można dołączyć raport patomorfologiczny $i, w$ miarę możliwości integracji ze szpitalnym systemem informatycznym, historie chorób i wyniki pozostałych badań pacjentów. Ponadto do cyfrowej archiwizacji można przekazywać preparaty konsultacyjne przed odesłaniem ich do jednostki macierzystej, co jest szczególnie przydatne w ewentualnej analizie porównawczej kolejnych badań histopatologicznych pochodzących od tego samego chorego. W przypadku konieczności wykorzystania materiału biologicznego do badań molekularnych obraz cyfrowy może stanowić jedyną dokumentację chorego [12]. Zewnętrzne kontrole jakości barwień i rozpoznań histopatologicznych można także prowadzić przy użyciu telepatologii i obrazów WSI. Wybrane przypadki w postaci obrazów cyfrowych są w tym celu przekazywane do jednostek akredytacyjnych. Wysyłanie preparatów mikroskopowych drogą pocztową zajmuje więcej czasu, a wysyłane szkiełka mikroskopowe są zagrożone zaginięciem lub uszkodzeniem. Wykonanie kontroli jakości metodą cyfrową przyspiesza ten proces i eliminuje potrzebę wysyłania konwencjonalnych preparatów. Wybrane platformy cyfrowe WSI mają oprogramowania do wewnętrznej kontroli jakości obrazów cyfrowych preparatów mikroskopowych [48].

Bez walidacji metody nie można stosować systemu WSI w rutynowej diagnostyce. Aby to było możliwe, należy wykazać równoważność diagnostyki opartej na obrazach cyfrowych $z$ diagnostyką konwencjonalną opartą na ocenie w mikroskopie świetlnym. Na wynik zgodności w przypadku obu technik wpływają głównie parametry infrastruktury komputerowej oraz doświadczenie patomorfologa w diagnostyce cyfrowej. Na poziomie konwencjonalnej diagnostyki mikroskopowej istnieją różnice $\mathrm{w}$ interpretacji poszczególnych przypadków, które wzrastają wraz z ich poziomem trudności. Wytyczne Collage of American Pathologists (CAP), Digital Pathology Association, Royal College of Pathologists zawierają rekomendacje dotyczące zastosowania 
systemu WSI w diagnostyce [49]. Zgodnie $z$ nimi laboratorium wykonujące diagnostykę cyfrową musi przeprowadzić wewnętrzną kontrolę jakości. Proces walidacji systemu WSI wymaga nakładu pracy od specjalistów patomorfologów i powinien być przeprowadzony w sposób imitujący proces rutynowej diagnostyki patomorfologicznej prowadzonej przez dany zakład. Zaleca się kwalifikację do walidacji nie mniej niż 60 przypadków materiałów należących do jednej kategorii: preparatów tkanek utrwalonych zabarwionych hematoksyliną-eozyną, preparatów cytologicznych, preparatów ze skrawków mrożonych $z$ badań śródoperacacyjnych itd. Oceniane przypadki muszą odzwierciedlać pełen zakres badań wykonywanych w ramach rutynowej praktyki danego zakładu patomorfologii. W procesie walidacji odstęp czasowy między oglądaniem szkiełek mikroskopowych i obrazów cyfrowych powinien wynosić co najmniej 2 tygodnie.

\section{Nauka cyfrowa}

Realizacja edukacji w patomorfologii polega na wspólnym oglądaniu preparatów mikroskopowych $z$ użyciem mikroskopów wielostanowiskowych. Technika ta ogranicza liczbę studentów lub patomorfologów $z$ jednoczesnym dostępem do preparatów. Alternatywną formą przekazywania obrazów jest edukacja $z$ wykorzystaniem określonego oprogramowania szkoleniowego $z$ wpisanymi statycznymi zdjęciami cyfrowymi preparatów mikroskopowych. Jednym $z$ pierwszych zastosowań technologii i platform WSI była właśnie edukacja - ze względu na stosunkowo dużą łatwość tworzenia bibliotek obrazów cyfrowych i zarządzania nimi. System WSI dostarcza ten sam cyfrowy obraz preparatów mikroskopowych zarówno wykładowcy, jak i nielimitowanej liczbie osób uczących się, także na odległość. Tym sposobem platformy cyfrowe spełniają funkcję zwielokrotnionego mikroskopu wielostanowiskowego. Użycie profesjonalnego oprogramowania pozwala na przedstawienie obrazów w sposób interaktywny między innymi dzięki możliwości wykonywania notatek, zadawania pytań, korzystania $z$ linków, klipów audiowizualnych oraz testów on-line wspomagających efektywność edukacji przed- i podyplomowej. Standaryzacja materiałów szkoleniowych pozwala na zapewnienie dostępu do takich samych zestawów obrazów cyfrowych preparatów mikroskopowych wszystkim uczestnikom szkolenia. Biblioteki obrazów cyfrowych mają unikalny charakter edukacyjny w przypadkach chorób rzadkich, małych biopsji, preparatów cytologicznych i przypadków konsul- tacyjnych oraz wszędzie tam, gdzie trudno jest wykonać liczne preparaty mikroskopowe dla wielu studentów.

Dla uniwersytetów inwestycja w systemy edukacyjne oparte na WSI jest opłacalna ze względu na obniżenie kosztów zakupów drogich mikroskopów i przygotowywania kolekcji preparatów mikroskopowych wraz z barwieniami dodatkowymi, które należy cyklicznie odtwarzać między innymi ze względu na łatwość uszkodzeń. Dodatkowym atutem obrazów cyfrowych jest możliwość korzystania $z$ biblioteki w sposób zdalny $z$ dowolnego miejsca i w dowolnym czasie za pomocą komputera, tabletu lub smartfonu $z$ dostępem do Internetu. Największym ograniczeniem edukacji cyfrowej jest natomiast jej całkowite uzależnienie od sprawnie funkcjonującej infrastruktury IT. Awaria spowolniająca system niewątpliwie ma bezpośredni wpływ na proces nauczania. Rozdzielczość obrazów WSI wysokiej jakości skanera może być mimo wszystko słabsza niż obrazów ocenianych pod mikroskopem. Użytkownicy systemów WSI najczęściej zgłaszają niezadowolenie $z$ powodu niewystarczającej prędkości pracy przeglądarek i opóźnień w ładowaniu ogromnych plików $z$ obrazami przy wolno pracującej sieci. Obecnie zakłady patomorfologii prowadzące edukację przy użyciu mikroskopii wirtualnej istnieją na wielu uniwersytetach na całym świecie. Postęp technologiczny ułatwia akceptację cyfrowego systemu nauczania przez studentów, a wyniki przeprowadzonych testów i egzaminów po wirtualnych szkoleniach były podobne do uzyskiwanych w przypadku tradycyjnej metody nauczania [50-52].

W ramach krajowych i międzynarodowych projektów naukowych platformy WSI umożliwiają wymianę zgromadzonych bibliotek obrazów cyfrowych. W tego typu działalności największe zastosowanie ma, oparta na pomiarach morfometrycznych i ilościowych, analiza obrazu w celu oceny ekspresji oznaczonych immunohistochemicznie białek lub amplifikacji genów. Istnieją równiė̇ aplikacje o specjalnym przeznaczeniu do analizy obrazów cyfrowych pochodzących z mikromacierzy tkankowych (TMA, tissue microarrays). Na jednym szkiełku mikroskopowym i dalej w jednym obrazie cyfrowym są widoczne próbki od wielu pacjentów, które mogą być następnie poddawane całościowej analizie lub każda próbka niezależnie może stanowić materiał do przeprowadzenia analizy indywidualnej. Podstawą badań naukowych są cyfrowe archiwa i repozytoria obrazów, które jednocześniè stanowią hurtownie danych. Ich wartość zwiększa się wtedy, gdy istnieje możliwość integracji $z$ bazą rozpoznań histopatologicznych oraz archiwum 
tkanek świeżych i utrwalonych zgromadzonych w biobankach [53, 54]. W celu włączenia pacjenta do badania klinicznego konieczne jest zapewnienie prawidłowego rozpoznania patomorfologicznego wraz $\mathrm{z}$ ujednoliceniem docelowej populacji pacjentów zgodnie $z$ ustalonymi kryteriami. W większości przypadków preparaty mikroskopowe i bloczki parafinowe chorych na nowotwory muszą być powtórnie ocenione $\mathrm{w}$ wyznaczonych centralnych zakładach patomorfologii. Obecnie, podobnie jak w przypadku konsultacji histopatologicznych, preparaty mikroskopowe są przesyłane pocztą do różnych ośrodków. Wymaga to czasu i zwykle wydłuża proces kwalifikacji chorych. Zastosowanie platform WSI do badań klinicznych w przyszłości pozwoli na znaczne skrócenie, uproszczenie i ujednolicenie procesu kwalifikacji. Ponadto standaryzacja oceny ilościowej oznaczonych immunohistochemicznie białkowych celów terapeutycznych przy użyciu oprogramowania do automatycznej analizy obrazów cyfrowych może usprawnić prowadzenie wielu prób klinicznych [55]. Możliwość tworzenia bibliotek obrazów cyfrowych, rozpoznań i próbek zapewni w przyszłości ich ewentualne wykorzystanie do dalszych badań nad nowymi celami terapeutycznymi.

\section{Podsumowanie}

Wydaje się, że technologia WSI to przyszłość patomorfologii. Obecnie systemy WSI już znalazły wiele nowoczesnych zastosowań zarówno w edukacji, diagnostyce, jak i badaniach naukowych. Dzięki wdrożeniu platform WSI możliwe są łatwe $\mathrm{i}$ interaktywne dzielenie się obrazami cyfrowymi oraz pełniejsza integracja obrazów cyfrowych $z$ innymi systemami informatycznymi. W przyszłości, być może, wystandaryzowane oprogramowania do analizy obrazu i komputerowego wspomagania diagnozy zostaną szerzej zaakceptowane w rutynowej diagnostyce. Ich zastosowanie pozwoli na bardziej obiektywną, precyzyjną i powtarzalną ocenę stopniowania w wybranych nowotworach wraz $z$ ilościową oceną biomarkerów o znaczeniu prognostycznym i predykcyjnym. W celu uzyskania wysokiej jakości obrazów cyfrowych konieczna jest standaryzacja obejmująca dwa zasadnicze procesy: po pierwsze proces wykonania preparatów mikroskopowych obejmujący wszystkie etapy, począwszy od przeddiagnostycznych, w tym krojenia, barwienia i zaklejenie preparatu; po drugie standaryzację wykonania zdjęcia cyfrowego zabezpieczającą właściwą rozdzielczość, liczbę skanowanych warstw i odległość między nimi, w tym kalibrację kolorów. Istotne jest zapewnienie otwartego, jednolitego formatu plików, w których są zapisywane obrazy cyfrowe. Na podstawie aktualnej wiedzy należy zakładać, że cyfryzacja w patomorfologii będzie przebiegać mniej dynamicznie niż w radiologii. Głównymi ograniczeniami pozostają wysoki koszt inwestycji w sprzęt i infrastrukturę, wydłużenie procesu diagnostycznego, trudności w uzyskiwaniu obrazów cyfrowych $z$ niektórych materiałów oraz wątpliwości i niechęć patomorfologów do wykorzystywania systemów WSI w rutynowej diagnostyce. $Z$ pewnością implementacja cyfrowej patomorfologii będzie przebiegać szybciej w takich dziedzinach, jak edukacja, badania naukowe, tworzenie bibliotek obrazów i archiwów oraz w prowadzeniu telekonsultacji. Wprowadzanie stałych udoskonaleń systemów WSI oraz zmiana nastawienia do patomorfologii cyfrowej stanowią wstęp do jej wykorzystania w rutynowej diagnostyce.

\section{Podziękowania}

Podziękowania dla Pana mgr. inż. Jerzego Mrozka za wsparcie w zakresie wiedzy technicznej i informatycznej.

\section{Finansowanie}

Praca została zrealizowana $z$ wykorzystaniem infrastruktury projektu nr POIG.02.03.00-14-111/13 sfinansowanego z Programu Operacyjnego Innowacyjna Gospodarka 2007-2013, Priorytet II. Infrastruktura strefy B+R, Działanie 2.3. Inwestycje związane $z$ rozwojem infrastruktury informatycznej nauki.

\section{Piśmiennictwo}

1. Pantanowitz L, Valenstein PN, Evans AJ, et al. Review of the current state of whole slide imaging in pathology. J Pathol Inform. 2011; 2: 36, doi: 10.4103/2153-3539.83746, indexed in Pubmed: 21886892.

2. Leong FJ, Leong AS. Digital photography in anatomical pathology. J Postgrad Med. 2004; 50(1): 62-69, indexed in Pubmed: 15048004 .

3. Al-Janabi S, Huisman A, Van Diest PJ. Digital pathology: current status and future perspectives. Histopathology. 2012; 61(1): 1-9, doi: 10.1111/j.1365-2559.2011.03814.x, indexed in Pubmed: 21477260 .

4. Farahani N, Parwani AV, Pantanowitz L. Whole slide imaging in pathology: advantages, limitations, and emerging perspectives. Pathol Lab Med Int. 2015; 7: 23-33, doi: 10.2147/plmi.s59826.

5. Wiley CA, Murdoch G, Parwani A, et al. Interinstitutional and interstate teleneuropathology. J Pathol Inform. 2011; 2: 21, doi: 10.4103/2153-3539.80717, indexed in Pubmed: 21633488.

6. Evans AJ, Chetty R, Clarke BA, et al. Primary frozen section diagnosis by robotic microscopy and virtual slide telepathology: the University Health Network experience. Hum Pathol. 2009; 
40(8): 1070-1081, doi: 10.1016/j.humpath.2009.04.012, indexed in Pubmed: 19540554.

7. Gifford AJ, Colebatch AJ, Litkouhi S, et al. Remote frozen section examination of breast sentinel lymph nodes by telepathology. ANZ J Surg. 2012; 82(11): 803-808, doi: 10.1111/j.14452197.2012.06191.x, indexed in Pubmed: 22924988.

8. Yagi Y, Gilbertson JR. Digital imaging in pathology: the case for standardization. J Telemed Telecare. 2005; 11(3): 109-116, doi: 10.1258/1357633053688705, indexed in Pubmed: 15901437.

9. Wilbur DC. Digital cytology: current state of the art and prospects for the future. Acta Cytol. 2011; 55(3): 227-238, doi: 10.1159/000324734, indexed in Pubmed: 21525733.

10. Park S, Pantanowitz L, Parwani AV. Digital imaging in pathology. Clin Lab Med. 2012; 32(4): 557-584, doi: 10.1016/j. cll.2012.07.006, indexed in Pubmed: 23078660.

11. Chlipala E, Elin J, Eichhorn O, et al. Archival and retrieval in digital pathology systems. Digital Pathology Association. 2011: 1-10.

12. Huisman A, Looijen A, van den Brink SM, et al. Creation of a fully digital pathology slide archive by high-volume tissue slide scanning. Hum Pathol. 2010; 41(5): 751-757, doi: 10.1016/j.humpath.2009.08.026, indexed in Pubmed: 20129646.

13. Weinstein RS. Innovations in medical imaging and virtual microscopy. Hum Pathol. 2005; 36(4): 317-319, doi: 10.1016/j.humpath.2005.03.007, indexed in Pubmed: 15891989.

14. Teodorovic I, Isabelle M, Carbone A, et al. TuBaFrost 6: virtual microscopy in virtual tumour banking. Eur J Cancer. 2006; 42(18): 3110-3116, doi: 10.1016/j.ejca.2006.04.033, indexed in Pubmed: 17027253.

15. Weinstein RS. Prospects for telepathology. Hum Pathol. 1986; 17(5): 433-434, doi: 10.1016/s0046-8177(86)80028-4.

16. Baak JP, van Diest PJ, Meijer GA. Experience with a dynamic inexpensive video-conferencing system for frozen section telepathology. Anal Cell Pathol. 2000; 21(3-4): 169-175, indexed in Pubmed: 11339564.

17. Rojo MG, García GB, Mateos CP, et al. Critical comparison of 31 commercially available digital slide systems in pathology. Int J Surg Pathol. 2006; 14(4): 285-305, doi: 10.1177/1066896906292274, indexed in Pubmed: 17041192.

18. Hipp JD, Fernandez A, Compton CC, et al. Why a pathology image should not be considered as a radiology image. J Pathol Inform. 2011; 2: 26, doi: 10.4103/2153-3539.82051, indexed in Pubmed: 21773057.

19. Stathonikos N, Veta M, Huisman A, et al. Going fully digital: perspective of a Dutch academic pathology lab. J Pathol Inform. 2013; 4: 15, doi: 10.4103/2153-3539.114206, indexed in Pubmed: 23858390

20. Glatz-Krieger K, Spornitz U, Spatz A, et al. Factors to keep in mind when introducing virtual microscopy. Virchows Arch. 2006; 448(3): 248-255, doi: 10.1007/s00428-005-0112-2, indexed in Pubmed: 16362822.

21. Treanor D, Jordan-Owers N, Hodrien J, et al. Virtual reality powerwall versus conventional microscope for viewing pathology slides: an experimental comparison. Histopathology. 2009; 55(3): 294-300, doi: 10.1111/j.1365-2559.2009.03389.x, indexed in Pubmed: 19723144.

22. Tuominen VJ, Isola J. The application of JPEG2000 in virtual microscopy. J Digit Imaging. 2009; 22(3): 250-258, doi: 10.1007/ /s10278-007-9090-z, indexed in Pubmed: 17999112.

23. Feldman M. Whole slide imaging in pathology: what is holding us back? Pathol Lab Med Int. 2015; 7: 35-38, doi: 10.2147/plmi.s81743.

24. Randell R, Ruddle RA, Mello-Thoms C, et al. Virtual reality microscope versus conventional microscope regarding time to diagnosis: an experimental study. Histopathology. 2013; 62(2): 351-358, doi: 10.1111/j.1365-2559.2012.04323.x, indexed in Pubmed: 22882289.

25. Thorstenson S, Molin J, Lundström C. Implementation of largescale routine diagnostics using whole slide imaging in Sweden: digital pathology experiences 2006-2013. J Pathol Inform. 2014; 5(1): 14, doi: 10.4103/2153-3539.129452, indexed in Pubmed: 24843825.

26. Pantanowitz L, Wiley CA, Demetris A, et al. Experience with multimodality telepathology at the University of Pittsburgh Medical Center. J Pathol Inform. 2012; 3: 45, doi: 10.4103/21533539.104907, indexed in Pubmed: 23372986.

27. Al Habeeb A, Evans A, Ghazarian D. Virtual microscopy using whole-slide imaging as an enabler for teledermatopathology: a paired consultant validation study. J Pathol Inform. 2012; 3: 2, doi: 10.4103/2153-3539.93399, indexed in Pubmed: 22439122.

28. Al-Janabi S, Huisman A, Vink A, et al. Whole slide images for primary diagnostics in dermatopathology: a feasibility study. J Clin Pathol. 2012; 65(2): 152-158, doi: 10.1136/jclinpath-2011-200277, indexed in Pubmed: 22031590.

29. Nielsen PS, Lindebjerg J, Rasmussen J, et al. Virtual microscopy: an evaluation of its validity and diagnostic performance in routine histologic diagnosis of skin tumors. Hum Pathol. 2010; 41(12): 1770-1776, doi: 10.1016/j.humpath.2010.05.015, indexed in Pubmed: 20869750 .

30. Leinweber B, Massone C, Kodama K, et al. Teledermatopathology: a controlled study about diagnostic validity and technical requirements for digital transmission. Am J Dermatopathol. 2006; 28(5): 413-416, doi: 10.1097/01.dad.0000211523.95552.86, indexed in Pubmed: 17012916.

31. Massone C, Soyer HP, Lozzi GP, et al. Feasibility and diagnostic agreement in teledermatopathology using a virtual slide system. Hum Pathol. 2007; 38(4): 546-554, doi: 10.1016/j.humpath.2006.10.006, indexed in Pubmed: 17270240.

32. Koch LH, Lampros JN, Delong LK, et al. Randomized comparison of virtual microscopy and traditional glass microscopy in diagnostic accuracy among dermatology and pathology residents. Hum Pathol. 2009; 40(5): 662-667, doi: 10.1016/j.humpath.2008.10.009, indexed in Pubmed: 19144382.

33. Al-Janabi S, Huisman A, Nap M, et al. Whole slide images as a platform for initial diagnostics in histopathology in a medium-sized routine laboratory. J Clin Pathol. 2012; 65(12): 1107-1111, doi: 10.1136/jclinpath-2012-200878, indexed in Pubmed: 23093511.

34. Campbell WS, Hinrichs SH, Lele SM, et al. Whole slide imaging diagnostic concordance with light microscopy for breast needle biopsies. Hum Pathol. 2014; 45(8): 1713-1721, doi: 10.1016/j. humpath.2014.04.007, indexed in Pubmed: 24913758.

35. House JC, Henderson-Jackson EB, Johnson JO, et al. Diagnostic digital cytopathology: are we ready yet? J Pathol Inform. 2013; 4: 28, doi: 10.4103/2153-3539.120727, indexed in Pubmed: 24392242 .

36. Kaplan KJ. Telecytopathology for immediate evaluation of fineneedle aspiration specimens. Cancer Cytopathol. 2010; 118(3): 115-118, doi: 10.1002/cncy.20079, indexed in Pubmed: 20544703.

37. Fine JL, Grzybicki DM, Silowash R, et al. Evaluation of whole slide image immunohistochemistry interpretation in challenging prostate needle biopsies. Hum Pathol. 2008; 39(4): 564-572, doi: 10.1016/j.humpath.2007.08.007, indexed in Pubmed: 18234276 . 
38. Lloyd MC, Allam-Nandyala P, Purohit CN, et al. Using image analysis as a tool for assessment of prognostic and predictive biomarkers for breast cancer: how reliable is it? J Pathol Inform. 2010; 1: 29, doi: 10.4103/2153-3539.74186, indexed in Pubmed: 21221174.

39. Minot DM, Kipp BR, Root RM, et al. Automated cellular imaging system III for assessing HER2 status in breast cancer specimens: development of a standardized scoring method that correlates with FISH. Am J Clin Pathol. 2009; 132(1): 133-138, doi: 10.1309/ /AJCPJVOSKAF2PCMY, indexed in Pubmed: 19864244.

40. Veta M, van Diest PJ, Willems SM, et al. Assessment of algorithms for mitosis detection in breast cancer histopathology images. Med Image Anal. 2015; 20(1): 237-248, doi: 10.1016/j. media.2014.11.010, indexed in Pubmed: 25547073.

41. DiFranco MD, O'Hurley G, Kay EW, et al. Ensemble based system for whole-slide prostate cancer probability mapping using color texture features. Comput Med Imaging Graph. 2011; 35(7-8): 629-645, doi: 10.1016/j.compmedimag.2010.12.005, indexed in Pubmed: 21269807.

42. Samsi S, Krishnamurthy AK, Gurcan MN. An efficient computational framework for the analysis of whole slide images: application to follicular lymphoma immunohistochemistry. J Comput Sci. 2012; 3(5): 269-279, doi: 10.1016/j.jocs.2012.01.009, indexed in Pubmed: 22962572.

43. Sertel O, Kong J, Shimada H, et al. Computer-aided prognosis of neuroblastoma on whole-slide images: classification of stromal development. Pattern Recognit. 2009; 42(6): 1093-1103, doi: 10.1016/j.patcog.2008.08.027, indexed in Pubmed: 20161324.

44. Yeh FC, Parwani AV, Pantanowitz L, et al. Automated grading of renal cell carcinoma using whole slide imaging. J Pathol Inform. 2014; 5(1): 23, doi: 10.4103/2153-3539.137726, indexed in Pubmed: 25191622.

45. Lu H, Papathomas TG, van Zessen D, et al. Automated selection of hotspots (ASH): enhanced automated segmentation and adaptive step finding for Ki67 hotspot detection in adrenal cortical cancer. Diagn Pathol. 2014; 9: 216, doi: 10.1186/s13000-014-0216-6, indexed in Pubmed: 25421287.

46. Akakin HC, Gurcan MN. Content-based microscopic image retrieval system for multi-image queries. IEEE Trans Inf Technol Biomed. 2012; 16(4): 758-769, doi: 10.1109/TITB.2012.2185829, indexed in Pubmed: 22311866.
47. Ho J, Parwani AV, Jukic DM, et al. Use of whole slide imaging in surgical pathology quality assurance: design and pilot validation studies. Hum Pathol. 2006; 37(3): 322-331, indexed in Pubmed: 16613327.

48. Pantanowitz L, Dickinson K, Evans AJ, et al. American Telemedicine Association clinical guidelines for telepathology. J Pathol Inform. 2014; 5(1): 39, doi: 10.4103/2153-3539.143329, indexed in Pubmed: 25379345.

49. Pantanowitz L, Sinard JH, Henricks WH, et al. College of American Pathologists Pathology and Laboratory Quality Center. Validating whole slide imaging for diagnostic purposes in pathology: guideline from the College of American Pathologists Pathology and Laboratory Quality Center. Arch Pathol Lab Med. 2013; 137(12): 1710-1722, doi: 10.5858/arpa.2013-0093-CP, indexed in Pubmed: 23634907.

50. Dee FR, Meyerholz DK. Teaching medical pathology in the twenty-first century: virtual microscopy applications. J Vet Med Educ. 2007; 34(4): 431-436, doi: 10.3138/jvme.34.4.431, indexed in Pubmed: 18287469.

51. Heidger PM, Dee F, Consoer D, et al. Integrated approach to teaching and testing in histology with real and virtual imaging. Anat Rec. 2002; 269(2): 107-112, doi: 10.1002/ar.10078, indexed in Pubmed: 12001217.

52. Van Es SL, Kumar RK, Pryor WM, et al. Virtual microscopy for learning and assessment in pathology. J Pathol. 2004; 204(5): 613-618, doi: 10.1002/path.1658, indexed in Pubmed: 15470688.

53. Hipp JD, Lucas DR, Emmert-Buck MR, et al. Digital slide repositories for publications: lessons learned from the microarray community. Am J Surg Pathol. 2011; 35(6): 783-786, doi: 10.1097/ /PAS.0b013e31821946b6, indexed in Pubmed: 21552111.

54. Hipp JD, Sica J, McKenna B, et al. The need for the pathology community to sponsor a whole slide imaging repository with technical guidance from the pathology informatics community. J Pathol Inform. 2011; 2: 31, doi: 10.4103/2153-3539.83191, indexed in Pubmed: 21845229.

55. Mroz P, Parwani AV, Kulesza P. Central pathology review for phase III clinical trials: the enabling effect of virtual microscopy. Arch Pathol Lab Med. 2013; 137(4): 492-495, doi: 10.5858/arpa.20120093-RA, indexed in Pubmed: 23544938. 